\title{
Feasibility of Sustainable Management of Secondary Atlantic Forest: Recovery and Mortality Rates of Damaged Trees Two Years After Harvesting ${ }^{\dagger}$
}

\author{
Pedro C. Britto ${ }^{1, *}$, Dirk Jaeger ${ }^{1}$, Stephan Hoffmann ${ }^{1}$, Renato C. G. Robert ${ }^{2}$, Alexander C. Vibrans ${ }^{3}$ and \\ Alfredo C. Fantini ${ }^{4}$
}

Citation: Britto, P.C.; Jaeger, D.; Hoffmann, S.; Robert, R.C.G.; Vibrans, A.C.; Fantini, A.C. Feasibility of Sustainable Management of Secondary Atlantic Forest: Recovery and Mortality Rates of Damaged Trees Two Years After Harvesting. Environ. Sci. Proc. 2021, 3, 39. https://doi.org/10.3390/ IECF2020-08484

Academic Editors: Angela Lo Monaco, Cate Macinnis-Ng and Om P. Rajora

Published: 20 November 2020

Publisher's Note: MDPI stays neutral with regard to jurisdictional claims in published maps and institutional affiliations.

Copyright: (C) 2020 by the authors. Licensee MDPI, Basel, Switzerland. This article is an open access article distributed under the terms and conditions of the Creative Commons Attribution (CC BY) license (http://creativecommons.org/licenses/by/4.0/).
1 Department of Forest Work Science and Engineering, University of Göttingen, Büesgenweg 4, 37077 Göttingen, Germany; dirk.jaeger@uni-goettingen.de (D.J.); stephan.hoffmann@uni-goettingen.de (S.H.)

2 Department of Forest Engineering and Technology, Federal University of Paraná (UFPR), Av. Prefeito Lothário Meissner 632, Curitiba 80210170, Brazil; renatorobert@ufpr.br

3 Department of Forest Engineering, University of Blumenau, R. São Paulo 3250, Blumenau 89030000, Brazil; acv@furb.br

4 Laboratory of Ecology and Management of Forest Ecosystems, Federal University of Santa Catarina (UFSC), Rodovia Admar Gonzaga 1346, Florianópolis 88034000, Brazil; alfredo.fantini@ufsc.br

* Correspondence: pedro.britto@gmx.de; Tel.: +49-(0)551-39-23580

+ Presented at the 1st International Electronic Conference on Forests - Forests for a Better Future: Sustainability, Innovation, Interdisciplinarity, 15-30 November 2020; Available online: https://iecf2020.sciforum.net.

\begin{abstract}
Subject to overexploitation in past centuries, the Atlantic Forest is now strictly protected, including a ban on timber harvesting. However, this strict protection is a very controversial issue. It resulted in a lack of willingness of landholders to conserve and possibly even expand native forest areas. The lack of knowledge on impacts of potential timber-harvesting causes conflicts between conservation and management of the remnant Atlantic Forest. We believe that sustainable forest management, with reduced harvesting impact, has the potential to generate income for the landowners while sustaining important ecological services of the forest. Therefore, we assessed the harvesting impact of a conventional harvesting method $(\mathrm{CM})$ and compared it to an alternative harvesting method (AM) in three different stands. We measured damage intensities of all remnant trees directly after harvesting and two years after harvesting. Tree damages were recorded in three different tree zones (crown, bole and leaning) and rated in three different intensity classes (minor, moderate and severe). Furthermore, we assessed the recovery and mortality rates of each damaged tree two years after harvesting. Improved AM harvesting reduced the impacts on trees with multiple damages, in particular to crown and bole damages combined. There is a strong relationship between steep terrains and crown damage. High mortality rates were related to stands with a high density of smaller trees and also to trees with leaning damage. Moreover, completely recovered trees were related to trees with light bole damage.
\end{abstract}

Keywords: reduced-impact logging; logging damages; tractor winch

Supplementary Materials: The following are available online at https:/www.mdpi.com/article/10.3390/IECF2020-08484/s1. 